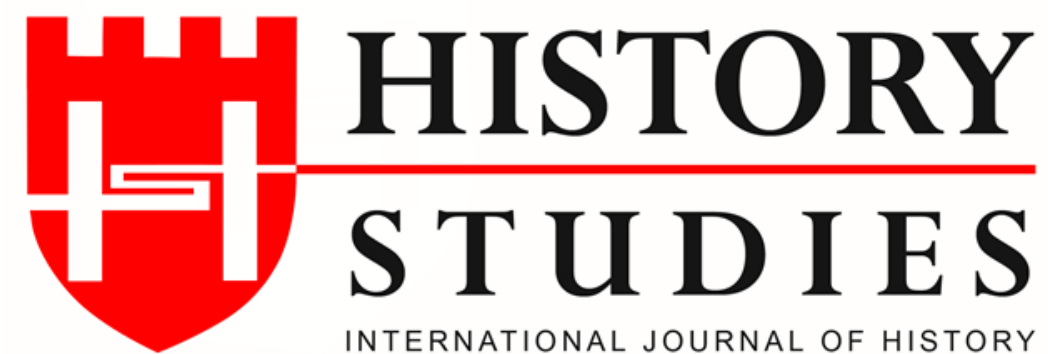

ISSN: 13094173 / (Online) 1309 - 4688 (Print)

Volume: 13, Issue: 2, April 2021

www.historystudies.net

\title{
ATHANASIUS' POLEMICAL USE OF GENDER AND THE WORD "EUNUCH" TO COMBAT EARLY ARIANISM
}

\author{
Athanasius'un Erken Aryanizm ile Mücadelede Cinsiyeti ve "Hadım" \\ Sözcü̆̆̈̈nü Polemik Amaçlı Kullanımı
}

\author{
Prof. Dr. Paul Brazinski \\ Saint Elizabeth University/USA \\ 87brazinski@cua.edu \\ ORCID ID: 0000-0002-5959-8663
}

\begin{abstract}
Makale Türü-Article Type : Araştırma Makalesi-Research Article
Geliş Tarihi-Received Date : $\quad$ 13.02.2021

Kabul Tarihi-Accepted Date : $\quad$ 04.03.2021

DOI Number : 10.9737/hist.2021.992
\end{abstract}
Atıf-Citation: Paul Brazinski, "Athanasius' Polemical Use of Gender and The Word "Eunuch" to Combat Early Arianism", History Studies, 13/2, April 2021, p. 371 - 378.



HISTORY STUDIES

Uluslararası Tarih Araştırmaları Dergisi International Journal of History 13/2, Nisan - April 2021

371-378

Araştırma Makalesi

\section{ATHANASIUS' POLEMICAL USE OF GENDER AND THE WORD "EUNUCH" TO COMBAT EARLY ARIANISM}

Athanasius'un Erken Aryanizm ile Mücadelede Cinsiyeti ve “Hadım” Sözcügünü Polemik Amaçlı Kullanımı

\section{Prof. Dr. Paul BRAZINSKI}

\begin{abstract}
Öz
Birçok araştırmacı geç antik dönemin değişimini ve devamlılığını araştırmaktadır. Bu dönemde, Aryanlar gibi heretik dini gruplar kendilerini Hristiyan olarak adlandırdıklarından Hristiyanlık anlayıșına tehdit oluşturmuşlardır. Aslına bakılırsa, ilim dünyası birbirine muhalif bu iki grubun Hristiyanlık anlayışının gelişimindeki rolünü anlamakta geç kalmıştır. Bu çalışmada Aryanların adetleri ve teolojisini Athanasius'un temel görüşünden ayırt etmek için erken dönem Hristiyan cinsiyet kullanımı incelenmektedir. Yine bu çalışma Aryanizm'de hadımların niçin hoş karşılandıklarını ve İskenderiye piskoposu Athanasius'un Hristiyanlık kimliğini korumak için rakipleriyle nasıl mücadele ettiğini ele alınmaktadır. Ayrıca geç antik dönemdeki hadımların tarihinde yer alan boşluğu doldurmayı amaçlamaktadır.
\end{abstract}

Anahtar Kelimeler: Cinsiyet, Arianizm, Athanasius, Hadımlar, Hristiyanlık Tarihi

\begin{abstract}
Several scholars have researched the change and continuity of the late antiquity world. During this period, heretical religious groups, such as the Arians, were threats to the identity of mainstream Christianity since both groups called themselves Christians. Indeed, scholarship has shown how closely contested these two groups were in hindsight in the development of "mainstream" Christianity. This paper looks at the early Christian use of gender, namely from Athanasius, to differentiate Arian practices and theology from his mainstream viewpoint. It argues why eunuchs were welcomed to Arianism and how Athanasius, the bishop of Alexandria, countered his opponents' advances to protect Christianity's identity. In the process, this paper also fills a lacuna in the history of eunuchs during Late Antiquity.
\end{abstract}

Keywords: Gender, Arianism, Athanasius, Eunuchs, History of Christianity 


\title{
Introduction
}

The history of eunuchs, especially in Byzantium, is in its infancy. However, several recent publications, such as those from Ringrose, Stevenson, and Tougher have tried to fill this lacuna. ${ }^{1}$ Some of these publications focus on earlier pagan topics when eunuchs were in their heyday, who were eligible to hold premier positions of spiritual power in the Late Roman period, such as the desirous post of priest of the Cybele. Other publications focus on later periods, such as the middle Byzantine era $\left(8^{\text {th }}-13^{\text {th }} \mathrm{c} A D\right)$, when eunuchs once again started to regain spiritual roles in Christianity, as witnessed with the famous eunuch Patriarchs of Constantinople - Germanos and Niketas. ${ }^{2}$ However, for this period in between - the fourth to the eighth century AD - several scholars turn to Peter Brown, whose monumental work The Body and Society explains the decline in roles for eunuchs in this era. ${ }^{3}$

Brown states that the decline of prestige of eunuchs, and the decline of sexual activity overall, is associated with the arrival of the new moral standards in early Christianity. ${ }^{4}$ These new standards emphasized asceticism - the control of one's body - which usually referred to moderating one's food consumption and sexual activities. This emphasis on asceticism greatly hindered eunuchs, who in Brown's eyes were seen as 'cheaters' since they did not have to worry about controlling half of these urges given their castration. ${ }^{5}$ Thus, the decline in eunuchs is generally connected with the rise of Christian morals and the lack of sources on them from the fourth to eighth centuries.

However, there are limitations to current scholarship. First, there are several narratives of Arian eunuchs in the major Christian history works on Arianism in this period that have never had an in-depth analysis - Athanasius, Sozomen, Socrates, Theoderet, Rufinus, and Philostorgius. ${ }^{6}$ These sources, written from both the Orthodox and Arian perspectives, discuss the various ecclesiastical roles of eunuchs in the early Arian Controversy (318-381) and how these 'third gender' individuals helped promote the heresy. ${ }^{7}$ For example, these eunuchs held prominent spiritual positions, as witnessed in the Bishop Leontius and imperial ambassador Eusebius. There is no comprehensive investigation on these examples to date.

Second, there is a great deal of scholarship that focuses on the formation of Orthodoxy by the process of separating it from the 'other.' Several scholars, such as Ehrman, Bauer, and Brown

\footnotetext{
${ }^{1}$ Kathryn M. Ringrose, The Perfect Servant: Eunuchs and the Social Construction of Gender in Byzantium (Chicago: University of Chicago Press, 2004); Walter Stevenson, "The Rise of Eunuchs in Greco-Roman Antiquity," Journal of the History of Sexuality 5, no. 4 (1995): 495-511; Shaun Tougher, Eunuchs in Antiquity and beyond (London: Classical Press of Wales and Duckworth, 2002). Also see Liz James, ed., Women, Men, and Eunuchs: Gender in Byzantium (London: Routledge, 2006); Mathew Kuefler, The Manly Eunuch: Masculinity, Gender Ambiguity, and Christian Ideology in Late Antiquity (Chicago: University of Chicago Press, 2001);

${ }^{2}$ Shaun Tougher, "Holy Eunuchs! Masculinity and eunuch saints in Byzantium," in Holiness and Masculinity in the Middle Ages, ed. P. H. Cullum and Katherine J. Lewis (Cardiff: University of Wales Press, 2005). Also, see Shaun Tougher, The Eunuch in Byzantine History and Society (London: Routledge, 2010).

${ }^{3}$ Peter Brown. The Body and Society: Men, Women and Sexual Renunciation in Early Christianity, twentiethanniversary ed. with a new introduction. ed. (New York: Columbia University Press, 2008).

${ }^{4}$ Brown, The Body, 33-36. For comparison, also see Taef Kamal El-Azhari, Queens, Eunuchs and Concubines in Islamic History, 661-1257 (Edinburgh: Edinburgh University Press, 2019).

${ }^{5}$ Brown, The Body, 387-390.

${ }^{6}$ Athanasius, History of the Arians, Epiphanius, Pararion, Sozomen, Church History, Socrates, Church History, Theoderet, Church History, Rufinus, Church History, \& Philostorgius, Church History. For translations of these works, see Philip Schaff and Henry Wace, eds., Nicene and Post-Nicene Fathers (Peabody, Mass.: Hendrickson Publishers, 1994)

${ }^{7}$ For a history of Arianism, see Michel R. Barnes and Daniel H. Williams, eds., Arianism after Arius (Edinburgh: T \& T Clark, 1993); Rowan Williams, Arius: Heresy and Tradition (Grand Rapids, Mich.: William B. Eerdmans, 2002); and Guido M. Berndt and Roland Steinacher, eds., Arianism: Roman Heresy and Barbarian Creed (New York, NY: Routledge, Taylor \& Francis Group, 2016).
}

\author{
History Studies \\ www.historystudies.net
}


have written major works with this methodology - utilizing themes from late antique society and culture to argue their conclusions. ${ }^{8}$ However, these publications have not used gender as a means of separation from heresy to Orthodoxy, which this article will do as well as a greater implication.

In this article, I will aid in filling this lacuna. First, I will showcase several narratives of where eunuchs were used in early Arianism (311-450 AD), demonstrating also how influential they were. Then, I will argue why eunuchs were so easily accepted into the Arian church as seen in Athanasius' theology. Overall, this will add to scholarship in viewing gender as a wedge used in Late Antiquity to separate mainstream Christianity from the 'heretical other.'

\section{1- Roles of Eunuchs}

The first Arian eunuch Socrates discusses, Chief-Eunuch Eusebius (not to be confused with the eunuch-bishop Eusebius), is perhaps the most famous example from the aforementioned Church Historians. ${ }^{9}$ Although Socrates does not provide much about him, he does write that Eusebius held an esteemed position in the imperial palace in Constantinople, which means that he managed his subordinates and had the ear of the empress, the unnamed daughter of Julius Constantius who was Constantius II's wife. ${ }^{10}$ According to Socrates and Athanasius, Arianism crept into the imperial court through this eunuch, as the bishop of Nicomedia, with the same name, targeted him to use his influence and ultimately spread Arianism. ${ }^{11}$ This resulted in the conversion of the empress and Emperor to Arianism, which created major waves as seen in the exiles of Athanasius. ${ }^{12}$ Beyond his role in introducing and spreading Arianism in the court, he also participated in extra-curricular activities as well, which was stereotypical of late antique eunuchs.

For example, from 351 to 354, Constantius Gallus, Constantius II's cousin, was made Caesar of the Eastern provinces. However, a dispute with his cousin resulted in emperor Constantius II ordering his execution..$^{13}$ However, the emperor reconsidered the murder, although it appears as though Chief-Eunuch Eusebius intentionally disregarded the order, an oversight for which the next emperor (Julian) would hold him accountable. Thus, according to our Church Historians, eunuchs were used to introduce and spread Arianism to the Byzantine emperors and their court. ${ }^{14}$ An unintended side effect was the emergence of a deadly inner-circle of Arian eunuchmurderers/assassins, which caused a wealth of violence in the imperial capital as well. But Arian eunuchs as Chief-chamberlain was not the only job that they held where they used violence, nor was this limited to the capital.

For instance, Arian eunuchs were also used as ambassadors and interrogators. Emperor Constantius II (d. 361) sent the eunuch-bishop Eusebius to Rome to convert Pope Liberius (d. 366). ${ }^{15}$ However, the bishop of the eternal city naturally did not give in. Thus, Eusebius sought spiritual help in this matter and went to the martyr shrine of the Apostle Peter in Rome, praying that the pontiff would change his mind. ${ }^{16}$ However, when Liberius heard of Eusebius' visit to the shrine, he was further upset with the eunuch-bishop for 'defiling' the holy site, which shows the

\footnotetext{
${ }^{8}$ Bart D. Ehrman, Lost Christianities: The Battles for Scripture and the Faiths We Never Knew (Oxford [England]: Oxford University Press, 2005); Walter Bauer, Orthodoxy and Heresy in Earliest Christianity (London: SCM Press, 1972); .Peter Brown, The Rise of Western Christendom: Triumph and Diversity, A.D. 200-1000, 10th ed. (Chichester, West Sussex: Wiley-Blackwell, 2013).

${ }^{9}$ Socrates, Church History II.2 \& III.1-2.

${ }^{10}$ Timothy E. Gregory, A History of Byzantium, 2nd ed. (Malden, Mass.: Wiley-Blackwell, 2011), 72-75.

${ }^{11}$ Socrates, Church History II. 2 \& Athanasius, History of Arianism V.37.

12 Athanasius, The Life of Antony: And the Letter to Marcellinus, ed. William A. Clebsch and Robert C. Gregg (Mahwah, N.J.: Paulist Press, 1980).

${ }^{13}$ Gregory, A History, 88-89.

${ }^{14}$ Gregory, A History, 88-89.

${ }^{15}$ Athanasius, History of the Arians V.36-37, V.41, \& VI.43.

${ }^{16}$ Athanasius, History of he Arians V.37.
} 
gendered and heretical tension regarding Catholic space and holiness. But when Eusebius would fail, the eunuchs of Ursacius and Valens would be sent as reinforcements to scourge the presbyters and deacons of Pope Liberius as a follow-up action. ${ }^{17}$ Moreover, Athanasius references another set of thuggish eunuchs that were dispatched to interrogate and convert Bishop Hosios of Cordova; however, they had difficulties tracking him down, as he fled from these possible captors. ${ }^{18}$ Thus, Arian eunuchs were used as interrogators to promote Arianism as well.

Eunuchs were also dispatched to other regions as well to help with military affairs. Emperor Constantius II (d. 361) sent the Arian eunuch Arsacius to assist Prefect Philagrius as they installed the new Bishop Gregory (of Cappadocia) in the patriarchate of Alexandria. ${ }^{19}$ As part of Arsacius' role, he is said to have attacked and persecuted several Christians in this time. ${ }^{20}$ The emperor also sent down other eunuchs as well to pillage Alexandria and spy on Orthodox activities for George.

Next, Arian eunuchs were used in the liturgy as well. For this, one must turn to Briso, who is only found in Socrates' Book II. ${ }^{21}$ Socrates does not provide many details on Brisbo, except that he is a eunuch of Empress Eudoxia. At the time, during the patriarchate of John Chrysostom (r.397-403), Arians were known for signing their antiphonal hymns in the morning and at night throughout Constantinople as part of their processions and worship. ${ }^{22}$ In this narrative, it appears as though this 'antiphonal' concept was invented by the Arians, meaning that they sang psalms in two corroborating choirs. Indeed, Arius' Thalia was written in this verse, which Ephraim the Syrian later tried to rework for Orthodoxy. ${ }^{23}$ On one specific night, Briso led the chanters down the streets of Constantinople; however, a party of Orthodox worshipers, led by John Chrysostom, held their own hymns in direct competition with their heretical counterparts. This interaction turned violent, as Briso was struck in the head with a rock and several other chanters around him were killed. ${ }^{24}$ Thus, eunuchs helped in the liturgy and worship in Arianism.

Finally, Arian eunuchs were used for odd-jobs too. In $336 \mathrm{AD}$, Arius, mere days before he was formally accepted back into the Church, died in a public bathroom, which contemporary Catholic sources said was only fitting, seeing as he was 'garbage.' ${ }^{25}$ Naturally, Orthodox believers viewed this as a divine sign of his heretical stance, which resulted in the area being seen as a sort of miraculous place for them. Thus, the emperor tasked his Arian court eunuchs to cover up this story with a more modest one and to deal with the issue of this location. ${ }^{26}$ Sozomen, Socrates, Epiphanius, and Rufinus all attest to these details. ${ }^{27}$ So, the imperial court eunuchs had an Arian patron buy the location and build a house on it, which was meant to terminate any Orthodox shrine from arising. Thus, they were also tasked with odd-jobs as well.

\section{2- Theology Section}

The narratives discussed in the first section have demonstrated that eunuchs were very influential and common in early Arianism. But the question remains as to why these "third gender"

\footnotetext{
${ }^{17}$ Athanasius, History of the Arians V.41.

${ }^{18}$ Athanasius, History of the Arians VI.43.

${ }^{19}$ Athanasius, History of the Arians II.2 \& VIII.5, Epiphanius, Panarion II.68.1 1.2, Sozomen, Church History III.6, Socrates, Church History II.28.

${ }^{20}$ Athanasius, History of the Arians, II.10.

${ }^{21}$ Socrates, Church History VI.8.

22 Wendy Mayer and Pauline Allen, John Chrysostom (London: Routledge, 2011).

${ }^{23}$ Arius, Thalia. Ephraim the Syrian. Philostrogius, Church History II.2, Theodoret, Church History II.19.

${ }^{24}$ Socrates, Church History VI.8; Socrates, Church History VI.16.

25 Theodoret, Church History I.13, Rufinus, Church History X.14, Epiphanius, Panarion II.68.6.9 \& II.69.10.3, Sozomen, Church History II.29-30, Socrates, Church History I.38.

${ }^{26}$ Sozomen, Church History II.29-30; Socrates, Church History I.38; Epiphanius, Panarion II.68.6.9; Rufinus, Church History X.14.

${ }^{27}$ Sozomen, Church History II.29-30; Socrates, Church History I.38; Epiphanius, Panarion II.68.6.9; Rufinus, Church History X.14.
} 
individuals were popular in this heretical movement. ${ }^{28}$ For this, I argue that one must turn to Arian theology and examine how contemporary Patristic authors viewed this demographic.

Athanasius' History of the Arians tries to explain this phenomenon, saying briefly that the rise of eunuchs in Constantius II's court, and in Arianism, was partially due to their declining role in ecclesiastical affairs and in their misunderstanding of theology. ${ }^{29}$ He wrote in VI. 38:

The Eunuch of Ethiopia indeed, though he understood not what he read Acts 8:27, believed the words of Philip, when he taught him concerning the Savior; but the eunuchs of Constantius cannot endure the confession of Peter, nay, they turn away when the Father manifests the Son, and madly rage against those who say, that the Son of God is His genuine Son, thus claiming as a heresy of eunuchs, that there is no genuine and true offspring of the Father. On these grounds it is that the law forbids such persons to be admitted into any ecclesiastical Council; notwithstanding which they have now regarded these as competent judges of ecclesiastical causes, and whatever seems good to them, that Constantius decrees, while men with the name of Bishops dissemble with them. Oh! Who shall be their historian? Who shall transmit the record of these things to another generation? Who indeed would believe it, were he to hear it, that eunuchs who are scarcely entrusted with household services (for theirs is a pleasure-loving race, that has no serious concern but that of hindering in others what nature has taken from them); that these, I say, now exercise authority in ecclesiastical matters, and that Constantius in submission to their will treacherously conspired against all, and banished [Pope] Liberius! ${ }^{30}$ (emphasis added)

He claimed that they cannot comprehend how Jesus Christ is the manifestation of God, the genuine Son of God. ${ }^{31}$ Instead, they saw the Son as the first creature, not being co-eternal with the Father. ${ }^{32}$ Within this lens, Arian Christology devalues the carnal meaning of the "God-Man", putting less emphasis on His human flesh in areas such as redemption and the incarnation. This results in the view of Jesus Christ as more of an intermediary, which results in an unequal Trinity overall.

So, in an Arian sense of imitating Christ, eunuchs might have attempted to make themselves sexless, as Jesus was thought to be and one's eternal soul. Origen earlier attempted this undertaking as well, as Eusebius states that he read the Matthew 19:12 literally: "For there are some eunuchs, which were so born from their mother's womb: and there are some eunuchs, which were made eunuchs of men: and there be eunuchs, which have made themselves eunuchs for the kingdom of heaven's sake. He that is able to receive it, let him receive it." ${ }^{33}$ This is one possible explanation for the acceptance of eunuchs in Arianism - that they devalued the carnal-fleshy aspect of Jesus Christ, which might have impacted their "imitation of Christ" practices.

Athanasius was also bothered by the fact that Arian eunuchs were rather steadfast in their theological stances and would not listen to "reason," as in his reading of Scripture. ${ }^{34}$ For example, he turns to the Ethiopian eunuch that Philip encounters on his trip toward Gaza in Acts 8:27.35

\footnotetext{
${ }^{28}$ Kathryn Ringrose, "Living in the Shadows; Eunuchs and Gender in Byantine," in Third Sex, Third Gender: Beyond Sexual Dimorphism in Culture and History, ed. Gilbert H. Herdt (New York: Zone Books, 2003).

${ }^{29}$ Athanasius, History of the Arians V.38.

${ }^{30}$ Athanasius, History of the Arians V.38.

${ }^{31}$ Athanasius, History of the Arians V. 38.

${ }^{32}$ Arianism book.

33 Virginia Burrus, The Sex Lives of Saints: An Erotics of Ancient Hagiography, kindle edition. ed. (Philadelphia: University of Pennsylvania Press, 2010). NIV translation.

${ }^{34}$ Athanasius, History of the Arians VI. 38.

${ }^{35}$ NIV of Act 8: 27-40, "26 Now an angel of the Lord said to Philip, "Go south to the road - the desert road - that goes down from Jerusalem to Gaza." 27 So he started out, and on his way he met an Ethiopian[a] eunuch, an important official in charge of all the treasury of the Kandake (which means "queen of the Ethiopians"). This man had gone to Jerusalem to worship, 28 and on his way home was sitting in his chariot reading the Book of Isaiah the prophet. 29 The Spirit told Philip, "Go to that chariot and stay near it." 30 Then Philip ran up to the chariot and heard the man reading Isaiah the prophet. "Do you understand what you are reading?" Philip asked. 31 "How can I," he said, "unless someone
}

\author{
History Studies \\ www.historystudies.net
}


Philip meets him on the road as the Ethiopian was struggling to understand the The Book of Isaiah. Philip helps him, which results in the latter finally comprehending the passage. Unlike the Ethiopian, Arian eunuchs refuse to listen to reason and logic. So, perhaps they were stubborn or ill-educated also, at least as stated from our one stubborn and biased source himself!

There was also a practical reason as to why eunuchs were so easily accepted into Arianism, a concept Athanasius and Augustine both agree on; in short, mutilated individuals were not allowed admittance to any ecclesiastical council nor into priesthood. ${ }^{36}$ Moreover, they were not supposed to receive communion either, something Leonitus from the vignettes above was criticized for. ${ }^{37}$ The fact that they were unrepresented in church affairs and could not receive communion provided additional impetus for their exodus to Arianism. Moreover, as mainstream Christianity seemed uncompromising on this topic, eunuchs would need to find acceptance elsewhere if they wanted to be Christians, something beyond the Roman Church. ${ }^{38}$ This practical reason too, in connection to their theology and concept of the body, also probably contributed as well to Athanasius' rejection of eunuchs in mainstream Christianity.

Regardless of their reason beyond their different theological interpretation, Athanasius' rhetoric on gender marks a stark turning point for women as well in the Christian tradition. ${ }^{39}$ Due to the Arian Schism, Athanasius writes harshly against these heretics, particularly to the several harlots and prostitutes that they tried to use to corrupt church leaders. He also uses this occasion call eunuchs "fruitless" regarding both their bodies and souls, an attitude which no doubt hurt their chances in being accepted into mainstream Christianity later. ${ }^{40}$ Concerning gender, young Arian males were also condemned for their advances on nuns and other pious Christian females. Thus, gender for Athanasius is used as a wedge between the mainstream 'us' and the heretical 'them', between proper concept of gender and adulatory as he saw it. And although his positions would not cause the tidal wave that Augustine's stance on Original Sin did, perhaps these ripples got the bishop of Hippo's thought started. ${ }^{41}$

\section{Conclusion}

In conclusion, this paper has demonstrated that Arian eunuchs were used in several capacities during the early stages of the Arian Controversy. They were used to introduce Arianism into the imperial court, to commit violence and thuggery against mainstream Christian leaders, participate

explains it to me?" So he invited Philip to come up and sit with him. 32 This is the passage of Scripture the eunuch was reading: "He was led like a sheep to the slaughter, and as a lamb before its shearer is silent, so he did not open his mouth. 33 In his humiliation he was deprived of justice. Who can speak of his descendants? For his life was taken from the earth.'[b]34 The eunuch asked Philip, "Tell me, please, who is the prophet talking about, himself or someone else?" 35 Then Philip began with that very passage of Scripture and told him the good news about Jesus. 36 As they traveled along the road, they came to some water and the eunuch said, "Look, here is water. What can stand in the way of my being baptized?" [37] [c] 38 And he gave orders to stop the chariot. Then both Philip and the eunuch went down into the water and Philip baptized him. 39 When they came up out of the water, the Spirit of the Lord suddenly took Philip away, and the eunuch did not see him again, but went on his way rejoicing. 40 Philip, however, appeared at Azotus and traveled about, preaching the gospel in all the towns until he reached Caesarea.

36325 Nicene Canon 1, "If anyone in sickness has been subjected by physicians to a surgical operation, or if he has been castrated by barbarians, let him remain among the clergy; but, if any one in sound health has castrated himself, it behooves that such an one, if [already] enrolled among the clergy, should cease [from his ministry], and that from henceforth no such person should be promoted. But, as it is evident that this is said of those who wilfully do the thing and presume to castrate themselves, so if any have been made eunuchs by barbarians, or by their masters, and should otherwise be found worthy, such men the Canon admits to the clergy."

${ }^{37}$ Theodoret, Church History II.19; Ephiphanius, Panarion II.68.11.1, Athanasius, History of the Arians II.20 \& II.28.

${ }^{38}$ Brown, The Body, 11.

${ }^{39}$ Barbara J. MacHaffie, Her Story: Women in Christian Tradition, 2nd ed. (Minneapolis: Fortress Press, 2006), 2226.

${ }^{40}$ Athanasius, History of the Arians VI.38.

${ }^{41}$ For more on Athanasius and Original Sin, see Thata Wiley, Original Sin: Origins, Developments, Contemporary Meanings (New York: Paulist Press, 2002). 
in the liturgy, and assist with odd-jobs as well. Females also contributed to Athanasius' concept of gender in Arianism as seducers as well.

Athanasius only provides one passing reference as to why so many eunuchs were Arian in this period, saying that they simply misread theology. However, this is something all heretics are accused of doing. Thus, I have suggested a few explanations as to why this phenomenon happened, such as in contextualizing this reference with Athanasius' Christology, Origen's reading of Scripture, and the practical reason of simply being unrepresented in church councils. Eunuchs were very important to the Arian movement, which also sheds much light on the chronological gap in current scholarship in the history of Byzantine eunuchs as well and the theology of the body in Arianism.

\section{Bibliography}

Athanasius, The Life of Antony: And the Letter to Marcellinus. Edited by William A. Clebsch and Robert C. Gregg. Mahwah, N.J.: Paulist Press, 1980.

BARNES, Michel R., and Daniel H. Williams, eds. Arianism after Arius. Edinburgh: T \& TClark, 1993.

BAUER, Walter. Orthodoxy and Heresy in Earliest Christianity. London: SCM Press, 1972.

BERNDT, Guido M., and Roland Steinacher, eds. Arianism: Roman Heresy and Barbarian Creed. New York, NY: Routledge, Taylor \& Francis Group, 2016.

BROWN, Peter. The Body and Society: Men, Women and Sexual Renunciation in Early Christianity. Twentieth-anniversary ed. with a new introduction. ed. New York: Columbia University Press, 2008.

The Rise of Western Christendom: Triumph and Diversity, A.D. 200-1000. 10th ed. Chichester, West Sussex: Wiley-Blackwell, 2013.

BURRUS, Virginia. The Sex Lives of Saints: An Erotics of Ancient Hagiography. Kindle Edition. ed. Philadelphia: University of Pennsylvania Press, 2010.

EHRMAN, Bart D. Lost Christianities: The Battles for Scripture and the Faiths We Never Knew. Oxford [England]: Oxford University Press, 2005.

EL-AZHARI, Taef Kamal. Queens, Eunuchs and Concubines in Islamic History, 661-1257. Edinburgh: Edinburgh University Press, 2019.

GREGORY, Timothy E. A History of Byzantium. 2nd ed. Malden, Mass.: Wiley-Blackwell, 2011.

JAMES, Liz, ed. Women, Men, and Eunuchs: Gender in Byzantium. London: Routledge, 2006.

KUEFLER, Mathew. The Manly Eunuch: Masculinity, Gender Ambiguity, and Christian Ideology in Late Antiquity. Chicago: University of Chicago Press, 2001.

MACHAFFIE, Barbara J. Her Story: Women in Christian Tradition. 2nd ed. Minneapolis: Fortress Press, 2006.

MAYER, Wendy, and Pauline Allen. John Chrysostom. London: Routledge, 2011.

RINGROSE, Kathryn. "Living in the Shadows; Eunuchs and Gender in Byantine." In Third Sex, Third Gender: Beyond Sexual Dimorphism in Culture and History, edited by Gilbert H. Herdt, 85-111. New York: Zone Books, 2003.

RINGROSE, Kathryn M. The Perfect Servant: Eunuchs and the Social Construction of Gender in Byzantium. Chicago: University of Chicago Press, 2004. 
SCHAFF, Philip, and Henry Wace, eds. Nicene and Post-Nicene Fathers. Peabody, Mass.: Hendrickson Publishers, 1994.

SCHOLTZ, Piotr O. Eunuchs and Castrati: The Emasculation of Eros. Princeton, N.J.: Markus Weiner, 1999.

STEVENSON, Walter. "The Rise of Eunuchs in Greco-Roman Antiquity." Journal of the History of Sexuality 5, no. 4 (1995): 495-511.

TOUGHER, Shaun. The Eunuch in Byzantine History and Society. London: Routledge, 2010.

. Eunuchs in Antiquity and beyond. London: Classical Press of Wales and Duckworth, 2002.

. "Holy Eunuchs! Masculinity and eunuch saints in Byzantium." In Holiness and Masculinity in the Middle Ages, edited by P. H. Cullum and Katherine J. Lewis. Cardiff: University of Wales Press, 2005.

WILEY, Thata. Original Sin: Origins, Developments, Contemporary Meanings. New York: Paulist Press, 2002.

WILLIAMS, Rowan. Arius: Heresy and Tradition. Grand Rapids, Mich.: William B. Eerdmans, 2002. 